Winter 2007

\title{
Local Matters: Internationalizing Strategies for U.S. Law Firms
}

\author{
Carole Silver \\ Northwestern University School of Law
}

Follow this and additional works at: https://www.repository.law.indiana.edu/ijgls

Part of the International Law Commons, and the Legal Profession Commons

\section{Recommended Citation}

Silver, Carole (2007) "Local Matters: Internationalizing Strategies for U.S. Law Firms," Indiana Journal of Global Legal Studies: Vol. 14 : Iss. 1 , Article 5.

Available at: https://www.repository.law.indiana.edu/ijgls/vol14/iss1/5

This Symposium is brought to you for free and open access by the Law School Journals at Digital Repository @ Maurer Law. It has been accepted for inclusion in Indiana Journal of Global Legal Studies by an authorized editor of Digital Repository @ Maurer Law. For more information, please contact rvaughan@indiana.edu.

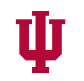

JEROME HALL LAW LIBRARY

INDIANA UNIVERSITY Maurer School of Law
Bloomineton 


\title{
Local Matters: Internationalizing Strategies for U.S. Law Firms
}

\author{
Carole Silver*
}

\begin{abstract}
The local nature of legal systems reduces the harmonizing impact that globalization has generated in other sectors of the economy. Despite the continuing importance of local differences and institutions, the world in which law and lawyers operate is increasingly connected, and national borders are receding as barriers to commerce. Lawyers and their firms must respond to the forces of globalization both as organizations and in connection with the services they provide. This article addresses the ways in which they are doing so by examining what it means for a law firm to be both a global and a U.S. firm. The article begins with a brief historical review and, in Section I, a discussion of the changes made by U.S. firms in their transformations to global competitors. Section II continues this historical review but broadens the focus from firms to include lawyers as well. Finally, Section III considers the credentials of lawyers active in the international legal services market. The analysis is based on two ongoing empirical studies, one of which examines the credentials of lawyers working in the foreign offices of U.S. law firms and the other focusing on foreign law graduates who earn a U.S. law school LL.M. degree, the one-year post-J.D. degree aimed at foreign law graduates. The article concludes with some thoughts on the challenges facing U.S.based firms as they respond to globalization by adding local lawyers to their rosters and local advisory services to their offerings. In becoming more local, the firms must struggle to maintain and redefine their U.S. identities.
\end{abstract}

* Senior Lecturer, Northwestern University School of Law. A portion of the research supporting this article was funded by a grant from the Law School Admission Council for the project, "Agents of Globalization in Law." Many thanks to Nicole DeBruin for her insight and energy in reviewing the article and providing excellent research support, to John O'Hare and the participants in the Globalization of the Legal Profession Symposium at the Indiana University School of Law for helpful discussions and comments, and to Sarah Babbitt, Brian Kohn, Julia McMurray, Joon Bom Pae and Ruslan Sadovnikov for valuable research assistance.

Indiana Journal of Global Legal Studies Vol. 14 \# 1 (Spring 2007)

OIndiana University School of Law 


\section{INTRODUCTION}

Law, today, remains stubbornly local, despite the importance of economic globalization. Courts have local rules and require local admission for lawyers appearing before them; local regulators and legislators are significant and remain responsive to interests of their electorates, and even legal education is local in important ways.' 'Geography matters in law and, consequently, for lawyers too. This is emphasized by each jurisdiction having separate licensing rules for lawyers practicing within its borders and, in each case, requiring compliance with local rules in order to advise on local law. ${ }^{2}$

This importance of the local in law impacts the way law firms respond to globalization. Law firms sell substantive legal advice, and that advice relates to the law of particular jurisdictions. U.S. law firms have capitalized on this in their international expansion, based upon the importance of U.S. law in governing international financial transactions and the U.S. capital markets to which foreign entities turn for raising funds. In contrast to the jurisdictional differences characteristic of law, globalization leads to uniformity in many sectors of the economy. Accounting, for example, has undergone a reorientation based on the emergence of global accounting standards and standard setters. ${ }^{3}$ This transition supports globalization of accounting service providers too, by unifying the relevant substantive knowledge. But law has not responded to globalization in the same way as services that are, or can be,

1. In the United States, for example, law schools teach theories and principles using state and federal cases, statutes and regulations. In certain courses, schools may focus on the law of just one jurisdiction, such as Delaware corporate law. While Delaware law exerts its influence nationally and even internationally, it is responsive to the local structure and balance of the Delaware political system.

2. See, e.g., Nat'l Conference of Bar Examiners \& American Bar Ass'n Section of Legal Educ. \& Admissions to the Bar, Comprehensive Guide to Bar Admission Requirements 2007 (Erica Moeser \& Margaret Fuller Corneille eds., 2006), available at http://www.abanet.org/ legaled/baradmissions/bar.html; National Conference of Bar Examiners, Bar Admission Offices, http://www.ncbex.org/bar-admissions/offices/ (last visited Jan.12, 2007). An important exception is England, which permits advising on English law without licensing, but the titles of solicitor and barrister are reserved for those who have satisfied the education and licensing requirements. See generally Richard L. Abel, England and Wales: A Comparison of the Professional Projects of Barristers and Solicitors, in Lawyers in Society: An Overview 39, 56 (Richard L. Abel \& Philip S. C. Lewis eds., 1995) (stating "[u]nlike lawyers in the United States and some Canadian provinces, English solicitors never claimed a monopoly over legal advice").

3. See generally David S. Ruder, Charles T. Canfield \& Hudson T. Hollister, Creation of World Wide Accounting Standards: Convergence and Independence, 25 Nw. J. IN T'L L. \& Bus. 513 (2005) (discussing changes in accounting standards to respond to an increasingly globalized market). 
standardized. As a result, law firms must struggle to become global organizations even as they deliver services tied to specific jurisdictions.

Despite the continuing importance of local differences and institutions, the world in which law and lawyers operate is increasingly connected, and national borders are receding as barriers to commerce. Lawyers and their firms must respond to the forces of globalization both as organizations and in connection with the services they provide. This article addresses the ways in which they are doing so by examining what it means for a law firm to be both a global and a U.S. firm.

Until quite recently, U.S. law firms could be characterized by three norms to which nearly every major U.S.-based firm adhered. "In this article, the "major firms" include those firms listed in Appendix A, a list of firms with overseas offices drawn from those firms included in the American Lawyer 100 and American Lawyer Global 100 rankings. ${ }^{5}$ The first of the three norms is that these firms were identifiable as based in one particular U.S. city from which they drew many of their clients and often the focus of their practice specialties. Second, all of their lawyers graduated from U.S. law schools with the basic three-year doctorate of jurisprudence (J.D.) degree. And third, the services offered by the firms were uniform in that they focused almost exclusively on U.S. law, albeit diverse in terms of the variety of U.S. jurisdictions they covered and in their substantive specialization. These three norms, especially the second and third, fostered the unique identity of U.S. firms as offering an internationally recognizable and highly valued approach to law and legal advising. ${ }^{6}$ But in responding to globalization and remaking themselves as global competitors, U.S. law firms have abandoned each of these norms. This article addresses those changes.

The article begins with a brief historical review and, in Section I, a discussion of the changes made by U.S. firms in their transformation into global competitors. Section II continues this historical review but broadens the focus from firms to include lawyers as well. Finally, Section III considers the abandonment of the second and third norms, described above, by examining the credentials of lawyers active in the international legal services market. The analysis is based on two ongoing em-

4. Baker \& McKenzie is an exception, as was Coudert Brothers, to a large extent, until its recent demise. On Coudert's dissolution, see Jonathan D. Glater, Law Firm That Opened Borders Is Closing Up Shop, N.Y. Times, Aug. 30, 2005, at C1.

5. The Am Law 200: Firms A to Z, AM. Law., June 2006, at 119, 119-124; The Am Law 100: Firms A to Z, Am. Law., May 2006, at 137, 137-142; The Am Law Global 100. A м. Law., Nov. 2005, at 111,111-114. More specifically, I have been following the global activities of the 63 firms listed in Appendix A.

6. See Carole Silver, Globalization and the U.S. Market in Legal Service-Shifting Identities, 31 Law \& Pol'y Int'L Bus. 1093, 1094-1100 (2000). 
pirical studies, one of which examines the credentials of lawyers working in the foreign offices of U.S. law firms while the other focuses on foreign law graduates who earn a U.S. law school LL.M. degree, the one-year post-J.D. degree aimed at foreign law graduates. ${ }^{7}$ The first study tracks the educational and licensing credentials of lawyers working in the overseas offices of the Appendix A firms. These firms support more than 300 overseas offices in more than 70 cities and include more than 5,000 lawyers. ${ }^{8}$ Combined, these two studies provide insight into the roles of U.S. and foreign-educated and licensed lawyers in the international legal services market. Finally, the article concludes with some thoughts on the challenges facing U.S.-based firms as they respond to globalization by adding local lawyers to their rosters and local advisory services to their offerings. In becoming more local, the firms must struggle to maintain and redefine their U.S. identities.

\section{The U.S. Perspective: From Local to National}

Nearly all major U.S. law firms have their origins as local organizations strongly rooted in the history, culture, and relationships revolving around a single locale in the United States. Location determined the nature of the practice specialties developed by firms, which in turn reflected the business of clients in that region. ${ }^{9}$ For Chicago firms, for example, manufacturing and railroads loomed large, leading to substantial corporate advisory practices, including rate regula-

7. Not all LL.M. programs are aimed at foreign law graduates, but here the discussion is limited to those that are. For a more general discussion of LL.M. programs, see Carole Silver, Internationalizing U.S. Legal Education: A Report on the Education of Transnational Lawyers, 14 CARDOzo J. Int'L \& Comp. L. 143 (2006). For a list of U.S. law school LL.M. programs, see American Bar Association, Section of Legal Education and Admission to the Bar, Post-JD Programs, http:// www.abanet.org/legaled/postjdprograms/postjdc.html\#2foreign (last visited Oct. 6, 2006).

8. The study of lawyers working in the offshore offices of the Appendix A firms is ongoing, as is the LL.M. study. I am in the process of updating the data, based on current information from law firm web sites. The data reported in this paper are based on a combination of information gained from law firm web sites and the Martindale-Hubbell directory during the period of 2004-06. LexisNexis:Martindale-Hubbell, http://www.martindale.com (last visited Oct. 6, 2006). Once completed, only 2006 data based on web site information will be included. The accuracy of the information reported here is dependent upon the accuracy and completeness of information reported by the law firms; moreover, it may not reflect the firms' activities in 2006 because of changes in the composition of the offices. Nevertheless, the trends described here are not in doubt.

9. One example of this local connection is provided in the history of Chicago law firm Winston \& Strawn, which represented slaughterhouses and railroads, two mainstays of the early period of Chicago's development. Winston \& Strawn: The First 150 Years 6-7, 9 (2004). It continued to counsel railroad clients, capitalizing on its experience representing the railroads in order to handle the "burgeoning product-liability suits" of the 1980s. Id. at 154.; see also Norman Diamond, A 
tion, antitrust, and general litigation services. ${ }^{10}$ For Texas firms, the oil and gas industry dominated." Washington, D.C. firms reflected their political homebase. ${ }^{12}$ New York-based law firms specialized in the finance-related work of their Wall Street clients. ${ }^{13}$ Even the recent tech-boom of the late 1990s supports this principle of law firm identity, with California-based law firms taking the lead on advising the emerging start-ups. ${ }^{14}$

Location also influences hiring decisions. Most of the firms in the "major U.S. firm" category hire many of their lawyers from among the graduates of the top national schools. Each of these firms puts emphasis on its ability to attract its yearly proportion of these graduates. But in addition, nearly all of these firms also hire graduates of local schools, whose reputations are regional rather than national and whose rankings on the U.S. News \& World Report list of the top U.S. law schools ${ }^{15}$ is below-sometimes well below-the top fifteen or twenty schools. ${ }^{16}$ The top Chicago firms, for example, hire graduates from Harvard, Yale, Colum-

Practice Almost Perfect: The Early Days at Arnold, Fortas \& Porter (1997); Robert V. Massey, Jr., Dechert Price \& Rhoads: A Law Firm Centennial (1975).

10. See, e.g., Herman Kogan, Traditions and Challenges: The Story of Sidley \& Austin 120 (1983).

11. See, e.g., Vinson \& Elkins LLP, About V \& E, History, http://www.vinson-elkins.com/ overview/overview.asp (last visited Oct. 9, 2006) ("In those days, the oil boom was already transforming Texas and the world, and Houston was home to much of the energy industry's activity. $V \& E$ 'cut its teeth' on oil and gas matters, and today remains one of the world's leading energy law firms, with offices in Austin, Dallas, Houston, New York, Washington, Beijing, Dubai, London, Moscow, Shanghai and Tokyo.").

12. See, e.g., Arnold \& Porter LLP, Law Firm Overview, Our History, http://www.arnoldporter. com/overview_history.cfm (last visited Oct. 9, 2006) ("[A] strong commitment to public service, and the personalities of Arnold \& Porter's founders still shape the firm today. Many of the firm's attorneys have held senior positions in such U.S. government agencies as the Departments of State, Justice, and Treasury, the Federal Reserve Board, the Federal Trade Commission, the Federal Communications Commission, the Central Intelligence Agency, and the Securities and Exchange Commission.").

13. See, e.g., Sullivan \& Cromwell LLP, History, 1879-1928, http://www.sullcrom.com/firm/ history (last visited Oct. 9,2006) ("Domestic and international finance always has been at the heart of the Firm's work.").

14. See, e.g., Wilson Sonsini Goodrich \& Rosati, About WSGR, http://www.wsgr.com/WSGR/ Display.aspx? SectionName = about (last visited Oct. 9, 2006) (“Wilson Sonsini Goodrich \& Rosati is the premier legal advisor to technology and growth enterprises worldwide, as well as the investment banks and venture capital firms that finance them.").

15. See, e.g., America's Best Graduate Schools, U.S. News \& World Rep., 2007, at 44, 44-47.

16. See Joyce Sterling, Ronit Dinovitzer \& Bryant Garth, Urban Law School Graduates 17-18 (July 6, 2006) (unpublished paper, presented at 2006 Law and Society Association Annual Meeting, Baltimore, Md., on file with author). 
bia, Stanford, the University of Chicago, and Northwestern, as do top firms based in New York, Los Angeles, and elsewhere. But in addition, Chicago firms hire locally from Chicago schools that do not enjoy as strong of a national reputation, including DePaul, Loyola, and IIT-Chicago-Kent. ${ }^{17}$ The fall interview list of Mayer Brown Rowe \& Maw, for example, a venerable Chicago law firm, includes each of these local schools. ${ }^{18}$ These same Chicago firms generally will not hire from non-Chicago schools with similarly local reputations, perhaps because they are not as familiar with those schools and cannot easily gain the comfort necessary to make a hiring decision. ${ }^{19} \mathrm{~A}$ comparison of Mayer Brown's law school interview sites with those of Akin Gump, a firm historically based in Texas with a strong presence in Washington, D.C., and Wilson Sonsini, a California firm, reveals this division. Akin Gump visits Baylor, Southern Methodist University, and the University of Houston, but not DePaul or IIT-Chicago-Kent (and visits Loyola only for a patent law program). Mayer Brown does not interview at any of these three Texas schools. Similarly, Wilson Sonsini's list includes Hastings and Santa Clara, schools not on the list of either Mayer Brown (for Chicago or Los Angeles) or Akin Gump, but sensible in view of Wilson's California home base.

While certain of these location-based identity characteristics remain intact, including local hiring differences, those firms interested in competing in the international market for legal services-that is, for non-U.S. clients and work based outside of the United States - have distanced themselves from their local roots in order to generate an identity more recognizable in the international arena. ${ }^{20}$ This new international identity nearly always includes a strong New York-based presence because New York epitomizes the importance of the United States to the international legal services market. New York's role is multifaceted. First, the ciry serves as the financial center for the United States in the international market. Second, to the extent that U.S. law itself is significant in the international economy, unless federal law applies, it is nearly always New York law that matters.

17. DePaul is ranked 80 on the 2007 U.S. News list, Chicago-Kent comes in at 60, and Loyola is ranked 70. America's Best Graduate Schools, supra note 15.

18. Mayer, Brown, Rowe \& Maw, Chicago Career Opportunities for Law Students, http://www. mayerbrownrowe.com/careeropportunities/campus.asp? nid $=860$ (last visited Oct. 9, 2006).

19. Comfort might come in the form of a high academic record or a recommendation from a trusted faculty member who also may have a formal relationship with the firm, or both. Compare, for example, Mayer Brown's list of schools at which it interviews, id., with the list for Akin Gump, a Texas-based firm with a strong presence in Washington, D.C. and New York, Akin Gump Strauss Hauer \& Feld LLP, OCI Recruiting, http:/www.akingump.com/recruiting/students_oci. cfm (last visited Oct. 9, 2006) to see this difference.

20. For more information about law firm movement to New York, see Silver, supra note 6. 
Third, the preeminence of several Wall Street law firms and their long-standing relationships to investment and commercial banking clients has made these firms the important benchmarks against which all others must compete. ${ }^{21}$ Related to this, the fees generated by representation of the powerhouse banking clients are among the most remunerative for elite law firms, because the work is consistent, highly sophisticated, and highly valued. As a result of these factors, having a New York identity furthers a firm's ability to compete for international business and, perhaps more important, having an identity based outside of New York does not.

The identity shift to New York was accompanied by a movement to New York as a location for practice. I have described this movement elsewhere and will not review the same ground here, ${ }^{22}$ but the point is important to understanding the ways in which U.S. firms are transforming into global organizations because firms are using New York as the location for their international practices. ${ }^{23}$ This may be formal or not, but it is nearly universal, and it sets the stage for the deviations from the second and third norms as well. This first norm of the pre-global period-the local U.S. identity - has not been completely abandoned, as evidenced by the continuing practice of local hiring. But most of the internationally active firms strive to be seen as national now, and each has a strong presence in New York. Of the sixty-three firms listed in Appendix A, only two do not have any office in New York; ${ }^{24}$ three additional firms with New York offices have only small groups of fewer than twenty. lawyers there. ${ }^{25}$ In other words, more than 90 percent of the Appendix A firms, which comprise the most international U.S.based firms, support substantial New York offices, as do 85 percent of the forty Appendix A firms not based in New York. As a result of this and similar changes discussed below, the firms are more homogenous now. At the same time, this

21. This relates to several issues, including the high fees earned by these firms in representing their banking clients, which are significant in the law firm market where money matters. Second, these firms bring access to their banking clients, crucial to certain-often non-U.S.—clients.

22. For more information about law firm movement to New York, see Silver, supra note 6.

23. The New York identity also may relate to revenue-generation for firms. According to the managing partner of a U.S. Am Law $100 \mathrm{frm}$, "if you aren't making money in New York, you're doing something wrong." Interview with Managing Partner \#1 (July 2006). This interview is part of a larger project of gathering information from law firm leaders regarding their strategies and experiences relating to globalization. Interviews that are part of this project will be cited "Interview with Managing Partner \#_."

24. The firms without a New York office are Faegre Benson and Shook, Hardy \& Bacon. See supra note 8.

25. The firms with small offices in New York are Howrey; Kilpatrick Stockton; and Squire, Sanders \& Dempsey. See supra note 8. 
movement toward national identities divides them from other, less internationally-minded firms that remain rooted in their jurisdictional attachments.

\section{The Personal Perspective: From National to Multinational}

Until quite recently, nearly all of the lawyers working for major U.S. law firms earned the basic three-year J.D. degree from a U.S. law school. This was a condition to sitting for the bar in most U.S. jurisdictions, and even where it was not, the major law firms almost never made an exception. Occasionally, a lawyer from outside of the United States, whose primary legal education was earned in another jurisdiction, might be associated with a U.S. firm temporarily as an accommodation to his home country law firm or employer to enable the U.S. firm to solidify a referral or client relationship with the home country entity. Often, these "foreign lawyers" were in the United States for a one-year LL.M. degree offered by U.S. law schools and wished to experience life in a large U.S. law firm as a capstone to their U.S. education. But the foreign lawyers typically were not on the same partnership track as J.D. graduates, and the expectation was that they would return to their home countries, taking their loyalty to the U.S. firms with them. ${ }^{26}$

In the early period of international expansion, U.S.-based firms emphasized uniformity and consistency of service, regardless of location. "Early period" here is not a fixed date, but rather relates to a particular firm's progression from domestically focused to internationally focused, and occurs at different times for different firms. In emphasizing uniformity, firms relied on the fact that all of their lawyers were U.S. educated and licensed, and they limited their advising to U.S. law in both their domestic and overseas offices. Uniformity of training was one way to achieve consistency in the quality of the advice and service provided by a firm's lawyers, regardless of location. Consider, for example, Willkie Farr \& Gallagher's description in 2000 of its London office lawyers: "All of the firm's attorneys practicing in the London Office are American attorneys admitted to practice in the State of New York who have worked at Willkie's New York office."27 Through this statement, the firm assures its current and potential clients as well as its own lawyers that the firm will deliver consistently high-quality advice based

26. See Ca role Silver, The Case of the Foreign Lawyer: Internationalizing the U.S. Legal Profession, 25 Fordham INT'L L.J. 1039, 1070 (2002).

27. Willkie Farr \& Gallagher, London Office, http://web.archive.org/web/19991118213551/ www.willkie.com/Offices/index-london.html (last visited Jan. 12, 2007); see also Silver, supra note 6 , at 1146 n.198. 
on the uniformity of experience of its lawyers. During the early period of international expansion, firms internalized the association of globalization and uniformity through the articulated goal of uniform service. They wanted their clients situated outside of the United States to receive the same service as did their domestic clients, and they sought to operate overseas while maintaining the same U.S. identities they had painstakingly created..$^{28}$

During this time, transnational communication was expensive and time zones mattered because the most efficient method of communication involved a phone conversation-requiring both parties to be awake at the same time. For a U.S. business executive sitting in Singapore, for example, which is approximately halfway across the world and fourteen hours from New York or Chicago, having access to U.S. law advice from a person physically present in Singapore was quite valuable. At the very least, it meant being able to get an answer during a twenty-four-hour period without finding the lawyer's home telephone number and waking her up in the middle of the night. During this period before e-mail and Internet usage became common (in other words, prior to 1992 or 1993), most firms furthered their international expansion by trying to duplicate in their foreign offices the kind of advising they offered in their U.S. offices-focused on selling U.S. law advice and covering as broad a swath as possible in terms of substantive law.

A foreign business interested in initiating activities in the U.S. might need U.S. legal advice from a foreign-office lawyer, as might a U.S. business with activities overseas. A description of Shearman \& Sterling's opening of its Paris office, taken from the firm's biography, was typical of the thinking during this early period:

The Firm policy is to confine our work to United States law and not attempt to practice foreign law. The policy is based on belief that when a client needs help under local law the best practice is to retain distinguished counsel of appropriate competence.

28. Compare Willkie Farr's current practice of staffing foreign offices, where each office outside of London includes lawyers educated exclusively outside of the United States. Today, Willkie's London office still is staffed exclusively with U.S. admitted lawyers, although it is not clear whether they have been trained in the firm's New York office, and one is admitted in Michigan and not in New York. Cravath continues to claim that it practices only U.S. law from London (compare Cravath's statement, $i d$.), but its lawyers there include four lawyers who earned an LL.M. and not a J.D. in the United States, and three lawyers who did not earn any U.S. law degree, but whose legal education was completed in a common law jurisdiction. See Cravath, Swain \& Moore LLP, London Lawyers, http://www.cravath.com/directory.aspx? location = London (last visited Jan. 12, 2007). 
... In the spring of 1963 the Firm opened its office at 23 rue Royale-near the famed Madeleine. It is attractive space, on the top floor under the eaves; Lufthansa has the ground floor office and Thos. Cook \& Son is directly across the street. Ed Tuck opened the office and continued until 1967 when he returned to New York and Dave McGovern was put in charge. When the office opened the work was $75 \%$ representation of American firms in their European contacts-such clients as First National City Bank, White, Weld \& Co., Dillon Read \& Co. Inc and OwensCorning Fiberglas. Today the work has shifted and approximately $75 \%$ of the work is representing European firms in their contact with America. ${ }^{29}$

This description would have been accurate for nearly all of the Appendix A firms during their initial periods of international expansion and generally until approximately 1990 . The intent was to practice U.S. law and to provide service to the firms' existing clients. If the foreign office also generated inbound U.S. work, so much the better.

Generally, U.S. firms have softened a bit on their goal of consistent and uniform service as they have proceeded along the path of globalization. One explanation for this softening relates to advances in technology and ease of communication. Today, if a firm wants to ensure that a client in Singapore has access to the same quality and substance of advice offered to a client in New York, technology enables the lawyer situated in New York to advise the client in Singapore with relative ease. The need for physical presence in the foreign jurisdiction has been reduced because of advances in communications technology.

At the same time that technology has enabled consistency and uniformity of advising, firms also have come to appreciate the importance of local differences in expectations and norms. Local differences have assumed a central role in the new global identities of U.S.-based law firms, which has led firms to abandon the second and third norms characteristic of the pre-global days. First, firms increasingly rely on local lawyers-lawyers educated and licensed in the jurisdiction in which the office is located - to staff their overseas offices. Second, U.S. firms no longer confine themselves to advising on only U.S. law in their foreign office practices.

29. Walter K. Earle \& Charles C. Parlin, Shearman and Sterling: 1873-1973, at 373-74 (2d ed. 1973). 
Rather, in those locations where local advising is permitted by regulation, ${ }^{30}$ they combine U.S. and local law advisory services to serve a mixed group of clients. These two developments in the activities and practices of U.S. law firms are examined in the following section.

\section{The Rising Role of Local Players}

When U.S. firms first opened international offices, they typically did so by sending a trusted and experienced home-office lawyer to manage the foreign branch. Offices often were tiny and, consequently, could not accomplish complex transactions or litigation representation. Nevertheless, they were proof of a firm's commitment to an international presence and allowed the firm to hold the hand of existing clients operating in the overseas location-and thereby ensure client loyalty - while often sending the work generated by the client home to be performed by lawyers working in the United States. Opening a foreign office was a defensive and protective maneuver, aimed at serving the firm's existing clients in the locations where clients were active and needy.

The growth in the size of foreign offices, in terms of number of lawyers, has been remarkable in the last twenty years or so. A study of the size of London offices since 1990 is illustrative. Thirty-seven of the Appendix A firms had London offices in 1990; these firms are identified in Appendix B. More than 60 percent of these London offices included only five or fewer lawyers in 1990, and 90 percent included just ten or fewer lawyers. Firms did not rely on English solicitors during this period because English regulation prohibited solicitors and foreign lawyers from joining forces to offer multinational advice from a single firm. Consequently, the focus of the U.S. law offices was on providing U.S. law advice.

30. Where not permitted by regulation, firms continue to hire lawyers who grew up and were educated locally. This enables them to capture local knowledge and relationships. One example of this practice can be seen in the Singapore office of Jones Day, where the firm utilizes Singapore-only licensed lawyers formerly affiliated with a local firm, Rajah \& Tann. See Jones Day-Singapore Office Attorney Profiles, http://www.jonesday.com (follow "Locations" hyperlink; then follow "Singapore" hyperlink; then follow "View Professionals" hyperlink) (last visited Oct. 9, 2006). Jones Day is not among those firms listed by the Singapore Attorney General as having affiliated with a local firm for purposes of advising on local law. See Singapore Government, List of Joint Ventures Registered With the Attorney General's Chambers as of January 4, 2007, http://www.agc.gov.sg/lps/docs/Joint_ Law_Ventures_Jan_2007.pdf; see also infra notes 62-63 (considering the practice of U.S. law firms with offices in China to include lawyers educated only in China, despite the prohibition on these lawyers from advising on local law). 
By January of 1992, the restrictive regulation had been lifted. Even then, however, the shift to a local or multinational approach was slow. According to a 1992 article on U.S. law firms in London, only

a few American firms employ solicitors and barristers with British qualifications, [and those that do] ... usually require them to have American qualifications too. What they are selling is mainly an American-style service and an American approach to transactions. This means there is a strong preference for lawyers, even among British recruits, with extensive experience in the [United States]. ${ }^{31}$

Today, this is no longer the preference in London nor is it the norm. In most London offices of the Appendix A firms, the balance is tipped toward British solicitors (and, in certain cases, also barristers) who have neither earned any U.S. legal education nor gained practice experience in the United States. ${ }^{32}$ These lawyers are advising primarily on English law for their U.S. firms. Fewer than one-third of the London lawyers working for Appendix A firms for which education information was available earned any U.S. legal education, whether J.D. or LL.M.

While this shift away from U.S.-only education and expertise was occurring, London offices also were expanding. Eighty-seven percent of the Appendix A firms now support offices in London; the average size of these London offices is thirty-six lawyers, revealing growth of more than 700 percent, compared to the fewer-thanfive lawyer size for the period ending in 1990. Similar stories of expansion of the number of lawyers, reliance on local lawyers, and adding local law expertise are repeated in other jurisdictions where permitted by the local regulatory regime. Thus, a pattern of growth and development emerges that generally has been followed by most firms in most locations. Initially, the foreign offices supported by U.S. firms were quite small. It was common to find offices staffed by only one or two lawyers; these offices served as "meet and greet" branches for the firms. Small outposts allowed firms to fly their flags overseas and identify themselves as "international," but they could not perform sophisticated transactional advisory or litigation-related services because of the limited number of lawyers working in the offices. Over time, these offices expanded in size and added local lawyers who offered local law expertise and relationships with local clients and authorities.

31. Edward Fennell, Americans Here to Stay, Times (London), May 5, 1992, at 25.

32. Fewer than one-third of all lawyers working for the Appendix A firms in London earned a U.S. J.D., according to research conducted as part of the Silver study. See supra note 8. 
Of course, the U.S. firms did not shift from an exclusive reliance on U.S. lawyers advising exclusively on U.S. law to a strategy comprised wholly of local law and lawyers. Instead, they combine local lawyers with U.S.-educated and licensed lawyers. The balance between U.S. and local lawyers is different in different jurisdictions. In locations such as London, where law practice is quite similar in approach and experience to the United States, and English law is as significant to transnational business and clients as is U.S. law, firms are likely to rely substantially on local lawyers. In certain London offices, English-educated lawyers comprise 80 to 100 percent of the lawyers in an office..$^{33}$

In other jurisdictions, such as China, where the experience with private law firm practice is only recent and local law does not occupy as substantial a position internationally, the firms rely more on U.S.-educated, experienced practitioners. For example, in Jones Day's Shanghai office, six of the seven lawyers earned U.S. J.D.s. ${ }^{34}$ And in the Beijing office of O'Melveny, eight of the ten lawyers in the office earned U.S. J.D.s and one additional lawyer earned his degree in the United Kingdom. ${ }^{35}$ Often, though, these U.S.-trained advisors have their personal histories tied to China, so that they offer local knowledge as well, including an understanding of the local substantive law and the political and cultural landscape, and also embrace established relationships with local officials and clients. Five of the seven lawyers in Jones Day's Shanghai office, for example, studied first in China before earning their law degrees elsewhere. ${ }^{36}$ The shift to including local lawyers and advising on local law reflects not only regulatory changes but also a growing awareness of the importance of local knowledge to the success of overseas offices.

Moreover, foreign offices are likely to be shaped by a substantive practice specialty today. In the early years of foreign expansion, U.S. firms typically selected a

33. All of the lawyers working for Bryan Cave in London, for example, earned their legal education in England, as did $89 \%$ of the lawyers working for Reed Smith in London. Seventy-four percent of Shearman \& Sterling's lawyers in London were educated in the United Kingdom. A different model is evidenced by Dewey Ballantine, where more than half of the lawyers in London received their primary legal education outside of the United Kingdom and United States. Twentysix percent of their lawyers earned J.D.s at U.S. law schools, $21 \%$ earned their legal education in the United Kingdom, and an additional 26\% earned LL.M.s in either the United Kingdom or United States or, in one case, both. Id.

34. See Jones Day-Shanghai Office Attorney Profiles, http://www.jonesday.com (follow "Locations" hyperlink; then follow "Shanghai" hyperlink; then follow "View Professionals" hyperlink) (last visited May 17, 2007).

35. See O'Melveny \& Myers LLP-Beijing Office Attorney Profiles, http://www.omm.com/ webcode/navigate.asp? codeanchor $=417$ (last visited Oct. 9, 2006).

36. See Jones Day-Singapore Office Attorney Profiles, supra note 30. 
generalist lawyer trained in the firm's home office to manage the overseas branch, with the expectation that the lawyer would either be able to answer or knowledgably refer any question a client might ask. Today, it is more common to find offices with larger numbers of lawyers offering more specialized or targeted services. That is, the firm will choose certain substantive specialties on which to focus their practices in particular locations, rather than try to be all things to all clients from each office. ${ }^{37}$ This is quite clearly the trend with overseas offices of the major U.S. law firms. For example, Arnold \& Porter's Brussels office focuses on antitrust and describes its practice there as

home to the firm's European competition/antitrust and regulatory practice. Grown out of Arnold \& Porter's historical roots as an antitrust and regulatory practice, we provide a sophisticated service designed to address the range of legal, public policy, and regulatory issues facing clients doing business in the current international economy. ${ }^{38}$

Each of the lawyers in the firm's Brussels office lists antitrust as the focus of his or her practice. Other Arnold \& Porter offices do not reflect the same emphasis. ${ }^{39}$ Another example of substantive focus is provided by Sidley's Frankfurt office, which "assists clients on securitization and structured finance, derivatives, and international capital markets transactions." Ten of the eleven lawyers in the office identify their primary area of practice as securitization. ${ }^{40}$

This discussion reveals that U.S. law firms are approaching globalization by becoming larger and more local in each jurisdiction in which they are operating.

37. This substantive-focus specialization for overseas offices was noted by the managing partner of one Am Law top $50 \mathrm{firm}$ and the head of international practice for another. Interview with Managing Partner \#1, supra note 23 and Interview with Managing Partner \#2 (Sept. 2005).

38. Arnold \& Porter LLP_-Brussels Office Homepage, http://www.arnoldporter.com/offices. cfm?office_id $=32$ (last visited Oct. 9, 2006).

39. For an example, see Arnold \& Porter LLP-London Office Homepage, http://www. arnoldporter.com/offices.cfm?office_id $=7$ (last visited May 17, 2007) ("Our London lawyers advise on a full range of regulatory, transactional and litigation matters, and focus especially on intellectual property and technology transactions and litigation, telecommunications, competition and corporate transactions. Arnold \& Porter is committed to strategic growth in London in these and orher areas with the same emphasis on quality of service and in-depth expertise as it provides in the United States.").

40. Sidley Austin LLP_Frankfurt Office Attorney Profles, http://www.sidley.com/lawyers/ alpha.asp? OfficeID $=26$ (last visited Oct. 9, 2006). 
In addition, they are focusing on certain specialty areas that play to the firms' strengths and existing clients, responding to their clients' demands for specialization. This is not so different from the ways in which other industries have internationalized. They have taken their activities, whether selling goods or services, and tried to sell the same sort of thing overseas, adapting it to the local market.

Consider Honda Motor Company's approach to internationalization. It first produced motorcycles in Japan in the 1940s. ${ }^{41}$ Just over ten years after the company produced its first motorcycle, it opened its first store in the United States in Los Angeles in 1959.42 But it took an additional twenty years before the company opened a plant in the United States to assemble motorcycles. In the meantime, in order to sell its products here, Honda adapted its product to U.S. regulations, including the Clean Air Act in the 1970s, which required it to tinker with the engine on its products-that is, to localize and adapt. ${ }^{43}$ Today, Honda employs more than 100,000 people in the United States, including 25,000 Americans. ${ }^{44}$ It continues to send Japanese employees and executives to the United States as well. To summarize, Honda has increasingly "gone local," enlarging its presence outside of Japan, utilizing local workers, and continuing to focus on the company's identity.

The comparison to lawyers is complicated by the fact that much legal advice is country specific. Consequently, a decision to sell internationally might mean offering advice on U.S. law to clients situated outside of the United States, or it might involve offering advice regarding the law of a particular jurisdiction, such as Japan, in that jurisdiction. In the United States, at least, regulators have tended to think that selling legal services is different than selling cars in terms of the way it is accomplished internationally. The regulation of legal practice takes a geographic approach-we license lawyers to practice in a particular physical jurisdiction and to practice the law of that jurisdiction. ${ }^{45}$

41. American Honda Motor Company, Honda in America, History, http://corporate.honda. com/america/history.aspx (last visited Jan. 20, 2007).

42. Id.

43. See American Honda Motor Company, Honda in America, History Timeline-1970s, http://corporate.honda.com/america/timeline.aspx (last visited Oct. 9, 2006).

44. American Honda Motor Company, Honda in America, Operations Overview, http:// corporate.honda.com/america/overview.aspx (last visited Oct. 9, 2006).

45. It is clear that international expansion should cause reconsideration of the ways in which the practice of law is regulated. See generally Cynthia L. Fountaine, Have License, Will Travel: An Analysis of the New ABA Multijurisdictional Practice Rules, 81 WASH. U. L.Q. 737 (2003) (discussing the successes and the shortcomings of amendments to regulations governing multijurisdictional practice); Gary A. Munneke, Multijurisdictional Practice of Law: Recent Developments in the $\mathrm{Na-}$ tional Debate, 27 J. Legal Prof. 91 (2003) (discussing how multijurisdictional practice reform is 
Traditionally, the need for local law advice was handled just as the Shearman \& Sterling description of its practice in Paris suggested: "when a client needs help under local law, the [firm] retain[ed] distinguished counsel of appropriate competence." Shearman would help in selecting the local counsel, and the firm's man in Paris (and they were nearly all men in the early period) would know which lawyers and firms could be trusted to perform competently and to refrain from trying to steal the client. U.S. firms developed strong referral relationships with local firms in the jurisdictions where they had foreign offices, which also generated new clients consisting of local companies interested in gaining a foothold in the United States or needing the credibility of a U.S. firm to help attract the attention of a U.S.-based financier.

But as clients became more exacting in their choice and management of outside counsel, they also grew to appreciate their local counsel, who often charged lower fees and more recently have come to resemble their U.S. law firm cousins. This resemblance is significant, and it brings U.S. LL.M. graduates into the story of globalization. These graduates, who earned their primary legal education outside of the United States, offer local expertise to international firms as well as a general familiarity with U.S. law.

As U.S. firms transformed themselves into global organizations and embraced local lawyers and local law, one might have expected them to capitalize on the increasing numbers of foreign LL.M. graduates as a central mechanism for their growth and reorientation. In the last ten years or so, there has been a substantial increase in the presence of foreign law graduates in U.S. law schools. ${ }^{46}$ More U.S. law schools are offering LL.M. degree programs for foreign law graduates, and the programs themselves have grown in size. For example, in 1996, forty-one U.S. law schools awarded the LL.M. degree to 1,046 foreign national students; by 2004, eighty-one law schools awarded LL.M. degrees to 2,269 foreign nationals. ${ }^{47}$ With this increase in numbers came increased pressure from LL.M. graduates for positions in U.S. law firms. The LL.M. graduates wanted to work in the United States

critical to the future of legal practice and to keep U.S. business competitive in the globalized market); Ca rol A. Needham, Multijurisdictional Practice Regulations Governing Attorneys Conducting a Transactional Practice, 2003 U. ILL. L. Rev. 1331 (analyzing how the increase in multijurisdictional practice is affected by various legal regulations and how the regulations need to be changed to facilitate multijurisdictional practice); Carole Silver, Regulatory Mismatch in the International Market for Legal Services, 23 Nw. J. INT'L L. \& Bus. 487 (2003) (examining the regulatory environment in which the interaction occurs between U.S. and foreign lawyers).

46. Silver, supra note 7, at 143.

47. Data provided by David Rosenlieb, Data Specialist, ABA Section of Legal Education and Admission to the Bar (data on file with author). 
after completing their U.S. law studies, and they were particularly interested in working for organizations that might employ them long-term at home. As the LL. $M$. became more common, and even expected, in foreign legal markets, graduates needed another way to distinguish themselves in their home markets. ${ }^{48}$ Experience working for a U.S. firm in the United States was just the ticket. These LL.M. graduates appeared to be the perfect choice for U.S. law firms, who could hire and train them in the United States-providing important links to domestic offices and firm culture, practices, and procedures-and then dispatch the lawyers to capitalize on their local knowledge in their home jurisdictions-literally picking up where they left off before enrolling in the LL.M. In this way, LL.M. graduates theoretically could provide firms with local knowledge as well as an appreciation for U.S. law and practice norms. They epitomize the bridge between U.S. and foreign lawyers and U.S. and foreign law that could facilitate the management of the newly global firm.

Despite this apparent symbiosis, LL.M. graduates report that it is exceedingly difficult to secure this sort of training and dispatch position with a major U.S. law firm. Firms were satisfying their increasing staffing needs without resort to large numbers of LL.M. graduates. In order to discover whether my LL.M. informants were aberrational in their description of the elusiveness of training and dispatching positions with U.S. law firms, I embarked on a project that has taken on a sort of "Where's Waldo" approach. ${ }^{49}$ By investigating the careers of LL.M. graduates, I was able to approach the issue of staffing U.S. firms' overseas offices from a different angle. If LL.M.s were not working for U.S.-based international firms, this project would provide insight into where they were and how they fit into the global market for legal services.

In fact, it is in the local firms that must compete with the overseas offices of U.S. firms that I found a substantial presence of LL.M. graduates. Forty-nine percent of 417 LL.M. graduates who responded to my survey on career trajectories are working for law firms, and 44 percent of these graduates work for foreign law firms that have no international offices (that is, they support offices entirely in one country, outside of the United States). ${ }^{50}$ They are illustrative of the impact of

48. See generally Silver, supra note 26 (discussing the increasingly international face of the legal profession).

49. E.g., Martin Handford, Where's Waldo (1987). The "Where's Waldo" series of children's books features a very detailed picture filled with tiny figures; the books present a game, the goal of which is to identify where Waldo is hidden in the scene. He might be hiding in a tree or riding a bus on a busy city street.

50. Carole Silver, The Role of U.S. Legal Education in Careers of International Lawyers 21-23 (July 6, 2006) (unpublished paper, presented at 2006 Law and Society Association Annual Meet- 
LL.M. graduates on foreign law firms and the international market for legal services, generally. These dual-educated lawyers have transformed local law firms by enabling the firms to offer their services directly to clients, regardless of where the client is based, without the necessity of using a U.S. law firm as translator, manager, or intermediary. Indeed, one of the motivations for earning an LL.M. in the United States is the credibility it brings in gaining opportunities to work with the best law firms in a graduate's home country and to gain the confidence of these firms' international clients. As one LL.M. graduate explained, "clients feel more comfortable with you if you have an LL.M. from a good U.S. law school. They think you understand more about the consequences of what they are doing." In certain countries, to gain access to and earn promotions at top firms, an LL.M. from the United States is absolutely necessary.

For local firms that now find themselves competing directly with U.S.-based firms' foreign offices, hiring graduates of U.S. LL.M. programs makes sense. It allows firms to promote themselves as competitive with the U.S. foreign offices by using LL.M.s as evidence of their lawyers' fluency in English, understanding of the U.S. legal system, and experience working with Americans.

While the presence of LL.M. graduates in local law firms helps local firms attract the attention of their U.S. clients, it may cause concern for the U.S. firms with offices in these jurisdictions. It is crucial for these offices to maintain their intermediary role between the client and local counsel. To respond, U.S. firms have taken another step in their efforts to protect their client relationships: they are buying out the competition, which is consistent with the general trend of consolidation in the legal services industry. ${ }^{51}$ The competition here consists of those local law firms, groups of local lawyers, and even individual lawyers, who have

ing, Baltimore, Md., on file with author). These 417 respondents earned their LL.M. at one of 18 U.S. law schools, in 1996, 1998, or 2000, including schools located in each major geographic region of the United States, and an equal number of public and private law schools. Id. at 2.

51. For reports of U.S. law firms' acquisitions of foreign firms and groups of lawyers, see Andre Brown, Intellectual Giants, PLC Cross-border Q., July-Sept. 2006, at 13, 14 ("In the past few years, [Howrey] has doubled the number of European offices with IP capability to four with Carl de Meyer's arrival in Brussels from Linklaters De Bandt, and the setting-up of a French outpost based on the leading former Paris IP boutique Cousté \& Cousté."), available at http://www.practicallaw.com/4-203-0456; Jonathan D. Glater, Company News: Big U.S. Law Firm Acquires Carnelutti of Italy, N.Y. Times, Sept. 6, 2003, at C4 (“McDermott, Will \& Emery, .. . acquired Carnelutti Sutido Legale Associato, a Milan firm that is one of Italy's largest, with 70 lawyers."); Hildebrandt International, 2006 Client Advisory, Global Expansion, http://www.hildebrandt.com/Documents.aspx? Doc_ID =2428 (last visited Oct. 10, 2006) ("Howrey Simon Arnold \& White merged with the Paris IP boutique Cabinet Couste \& Couste, Paul Hastings Janofsky \& Walker acquired the Taiyo Law Office in Japan, and Squire Sanders \& Dempsey combined with Warsaw's Wiater 
worked with the U.S. firms and their clients and may control client relationships. By bringing local counsel in-house, the U.S. firms attempt to offer clients onestop shopping for their legal needs, regardless of the jurisdiction involved.

At the same time, bringing local counsel in-house enables U.S. firms to compete more effectively on fees for their services. A single firm can offer greater flexibility on fees, including local counsel fees, than is possible if the firm must contract with independent service providers for part of its advice on a transaction or dispute..$^{52}$ This might help win retention when price matters - which it increasingly does, but the importance of price and flexibility differs in particular jurisdictions and practice areas. China, for example, is notoriously price-sensitive. If a U.S. firm agrees to take eighty cents on the dollar in legal fees, but must charge full price for local counsel fees, it might lose the work to another firm that can offer lower fees on all of the services required. Certain practice areas also may engender competition over price; the project finance work in Germany is dominated by the foreign law firms, but the work also is the subject of price "dumping," which means that firms that have invested in this area in the past and are expected to do so in the future are the main competitors. ${ }^{53}$

Finally, bringing local counsel in-house to the U.S. firm also provides an opportunity to inculcate the local counsel lawyers with the U.S. firm's approach to client service and thereby offer a more consistent and uniform service. This last point may be more theory than practice, but many lawyers describe a difference in quality, reliability, and client-consciousness for lawyers working for their firm compared to those working in independent firms. ${ }^{54}$

The shift to a local focus also makes sense from a human resources perspective. It is expensive to send U.S. lawyers to foreign offices, and as firms offer increased depth and specialization in their foreign offices they need more people,

Law Office."). The International Financial Law Review regularly reports on the movements of lawyers and offices as well.

52. Interview with Managing Partner \#2, supra note 37.

53. See JUVE Online Resources, German Commercial Law Firms 2004: A Handbook for International Clients (2004), http://www.juve.de/cgi-bin/juve/ihb_introtxt.cgi ?kapitel= Banking\%20and\%20Corporate\%20Finance (last visited Oct. 10, 2006).

54. E.g., Interview with LL.M. Graduate \#20 (Dec. 2003) (describing the difference between lawyers in jurisdictions one and two, compared to those in jurisdiction three). Each jurisdiction is located in the same world region where English is not the native language. In jurisdictions one and two, where the firm does not have offices, the local lawyers' language skills are inadequate and they “just don't get it." But in jurisdiction three, where the firm has an office, the "lawyers are bilingual and they do get it. If they tell me $\mathrm{x}$, then $\mathrm{x}$ is right under [local] law." Id. This interview is one of more than 30 conducted with graduates of U.S. LL.M. programs as part of my ongoing research. 
which simply magnifies the cost factor. Moreover, cost is not limited to salary differences for U.S. lawyers. It is difficult to get U.S. lawyers to accept a foreign assignment; it is risky for career development for younger lawyers (few, if any, firms, besides Baker \& McKenzie, tout foreign experience as required for management positions), and an overseas assignment causes problems with reintegration when the lawyer returns to the United States and seeks to reestablish relationships with clients that had been taken over by other lawyers who did not leave home.

Finally, U.S. firms found willing collaborators among local lawyers. Moving to a U.S. law firm may allow younger local lawyers to escape their relatively low status in a local law firm, where older lawyers jealously guard the privileges of seniority and a rigid promotion structure that does not reward on a basis that allows younger lawyers to get ahead of their elders. A move to a U.S. firm also might render younger lawyers more appreciated by their home country clients. A German client may appreciate a German-trained lawyer in a U.S. firm more than he or she would appreciate the same lawyer in a German firm, because of different expectations. ${ }^{55}$

Today's general approach to globalization resembles the exception to the norms of the earlier period. While nearly all U.S.-based firms began their international expansion by relying on U.S.-educated and licensed lawyers who advised exclusively on U.S. law, there was an alternative minority model. It was defined by Baker \& McKenzie ${ }^{56}$ but also was characteristic of Coudert Brothers and White \&

55. JUVE Online Resources, German Commercial Law Firms 2003: A Handbook for INternational Clients (2003), http://www.juve.de/cgi-bin/juve/hb_introtxt.pl?teil=National\%20 Review (last visited Oct. 10,2006) ("With 1:1 leverage now a faint memory at the leading firms, the culture of assured partnership has disappeared; individual career development has taken over. This has happened both on a partner-level as well as with associates. Senior associates in particular are finding it harder to make partner-there were some notable surprises over the past year at the top six firms-and are welcomed with open arms by competitors who need to build up precisely that level within the firm in order to be able to improve quality control while increasing partner track and-it is hoped-profitability. The recruitment market is thus becoming defined (at least at the upper end of the market, and almost every development there has trickled down to the orher firms) by the competition for experienced associates. There are at established and large practices more than enough partners, even though many law firm managers in private remark that their firms would benefit from some slimming down of the older partner generation. This evolution of law firm structures has loosened partner loyalty considerably as well. With German firms and the German offices of international firms now looking gradually more and more like their counterparts in London and New York, an increasing number of experienced partners see little difference in working at an established German firm or a newcomer from abroad.").

56. Baker \& McKenzie has offices in more than 65 jurisdictions. See Baker \& McKenzie, Firm Profile, Our Global Systems, http://www.bakernet.com/BakerNet/Firm + Profile/Our+Global+Systems/ default.htm (last visited Oct. 10, 2006). 
Case $^{57}$ to a lesser extent. It involved using local lawyers in foreign offices, establishing a presence in many more locations than just those central commercial centers that hosted most of the international law firms, and supporting larger offices in certain locations than was the norm for international firms. During the early period of international expansion, Baker's approach was ridiculed by many of the large firms. In the mid-1990s John Flood reported on a lawyer's description of Baker as "Baker \& McDonalds," and perfectly captured the concern about differences in quality of the lawyers in Baker's many foreign offices. The lawyer commented, "Part of the problem is Baker \& McKenzie use locals in all their offices, unlike other firms that send out their own people."' 58 The foreign-educated and licensed lawyers working for Baker lacked just what it was that made U.S. lawyers valuable-U.S. legal education and training in U.S. law practice at a sophisticated U.S. firm. ${ }^{59}$

Two important pressures are shaping the way U.S. firms expand internationally. First is the interplay between specialization and jurisdictional constraints. In the early years of international expansion, foreign offices often housed a generalist, who had enough breadth and experience to handle inquiries relating to many topics. During that period, U.S. law firms were ready to offer advice relating to U.S. experience and U.S. law. This covered both the advisors who had experience in a particular kind of transaction that was being exported to a new jurisdiction-such as hostile tender offers-and the expert in U.S. antitrust law. ${ }^{60}$ But today's clients are more demanding with regard to expertise (more hands-on managers of legal services and costs), and at the same time, the jurisdictional con-

57. White \& Case supports offices in more than 30 jurisdictions outside of the United States. See White \& Case, Offices, http://www.whitecase.com/Locations/Offices.aspx? $\mathrm{n}=1$ (last visited Oct. $10,2006)$.

58. John Flood, Megalawyering in the Global Order: The Cultural, Social and Economic Transformation of Global Legal Practice, 3 Int'L J. Legal Prof. 169, 195 (1996). Flood gathered advice from lawyers about generating business in foreign offices, including the following: "We have to control quality and you can't do it through alliances.... When you open a new office you have to put someone in who's good and you trust, and so you lose them for a while." Id. "You have to send the best otherwise you won't get any work." Id. "Many overseas offices don't make a profit because they send a partner who is loyal and trustworthy but not necessarily the best for rainmaking." Id.

59. Baker's approach is a corollary of its cost-center organization; that is, each office was its own cost center so there was no motivation to relate the work of a particular office to the clients or global strategy of the entire firm. The Battle of the Atlantic, Economisr (London), Feb. 26, 2000, at 79, 80 ("Rivals sneer at Baker as a 'franchise' operation: one with the same nameplate screwed to the doors of all its offices, but really consisting of a conglomeration of local partnerships that act independently and keep their own profits."). This is unlike most other firms.

60. See John E. Morris, The Handbag Wars, A м. Law., May 1999, at 69, 129; Silver, supra note 6, at $1094-1100$. 
straints in many countries have fallen away so that firms are authorized to offer specialists who advise on local law as well. There have always been topical drivers, but there were jurisdictional limits because regulation protected the local legal profession against advice offered by outsiders, and it was difficult for outsiders to gain expertise in the local system. Today, the jurisdictional limits have fallen away, making topical drivers more important. We can see this simply as a consequence of the push for free trade and deregulation.

The second pressure relates to the interplay of local professional regulation and the characteristics of the local legal market. Important characteristics include the sophistication and organization of local law firms, as well as what might be considered the comfort level of U.S. law firms in a particular jurisdiction. This comfort level relates to a variety of factors indicating the closeness of local legal professionals to U.S. norms and expectations of practice, including the nature of the legal system itself, English language skills, similarity in terms of service to clients, and experience with complicated commercial transactions, among others.

As a result of these two factors, the offices in certain cities are remarkably local. They are dominated by lawyers educated in the country of the office; the advice offered includes local law advice, and the connection to the United States is thin, whether through legal education, bar admission, or training in a U.S. office. An example is Frankfurt, where there is no regulatory restriction against a single firm supporting local and foreign lawyers advising on local and foreign law. The reliance on local lawyers is supported by excellent English language skills and sophisticated local legal education. ${ }^{61}$ Fewer than 15 percent of the lawyers in Frankfurt offices of the Appendix A firms graduated with a U.S. J.D. degree; approximately 25 percent had earned a U.S. LL.M. and slightly more than 15 percent were admitted to practice in the United States. This local domination also is related to the fact that many of the Frankfurt offices were acquired as groups from local law firms or through acquisition of an entire local firm. ${ }^{62}$

Other jurisdictions are quite different. Offices in China, for example, are staffed with more U.S. educated lawyers than not, and local regulation prevents Chinese lawyers working with foreign law firms from practicing local

61. In addition, it is relatively common for German lawyers in U.S. firms to have earned a U.S. LL.M.

62. See The Global 100: Leaders and Laggards, Outposts and Outlooks: A Region-by-Region Examination of the Worldwide Legal Market, AM. LAw., Nov. 2001, at 90, 91; Brenda Sandburg, German Disunity, Am. Law., May 2006, at 206 (discussing the break up of Germany's largest independent firm); Brenda Sandburg, They'll Take "Meinhattan", Am. Law., May 2006, at 196 (discussing recent trends in the acquisition of German firms by U.S. firms). 
law $^{63}$ On the other hand, local legal, cultural, and political knowledge is crucial in China, and the U.S. firms' offices are filled with Chinese nationals who have studied law in the United States, either in J.D. or LL.M. programs. Professional regulation matters, but once U.S. firms are permitted to enter a jurisdiction, they tend to find ways to work alongside of regulatory hurdles by capitalizing on the blurry boundary between legal and business advice, as well as the roles of negotiator and advisor in contrast to litigator. An example is Shearman \& Sterling in Beijing, where the firm supports an office of two partners and fourteen associates.$^{64}$ Each of the partners earned a J.D. degree in the United States and neither completed any degree program in China. In contrast, eleven of the associates earned degrees in China and each of these also completed either a J.D. or LL.M. in the United States. ${ }^{65}$ This combination of local and U.S. education is typical and reveals a strategy of capitalizing on local knowledge while using U.S. legal education as a unifying mechanism.

\section{Conclusion}

In 2006, two qualities characterize foreign offices: they are larger and more local in terms of the education and licensing backgrounds of the lawyers working there than they ever have been. That is, they look a lot more like the Baker \& McKenzie model, and firms have universally abandoned the three pre-globalization norms. This does not mean that U.S. lawyers are absent. Instead, most offices include a combination of U.S. and local lawyers. But, in many jurisdictions, there are many more locals than Americans, and in certain offices, such as in Germany and Italy, for example, the Americans are few and far between.

Of course there are holdouts; Davis Polk describes itself as having the "largest contingent of lawyers in Germany practicing exclusively U.S. law,' ${ }^{\prime 66}$ and it

63. See Anthony Lin, Shanghai Bar Association Upset With Practices of Foreign Firms, N.Y. L.J., May 17, 2006, at 1,1 ("A fiery April 17 memo by the Shanghai Lawyers Association has accused foreign law firms of conducting 'illegal business activities' by skirting regulations prohibiting them from practicing Chinese law.").

64. See Shearman \& Sterling LLP_Beijing Office Attorney Profiles, http://www.shearman. com/offices (follow "Beijing" hyperlink; then follow "Lawyers" hyperlink) (last visited Oct. 10, 2006).

65. One associate was educated in Singapore, and no education information was provided for two associates. See id.

66. Davis Polk \& Wardwell-Frankfurt Office, http://www.dpw.com/offices/frankfurt.htm (last visited Oct. 10, 2006). 
supports only five lawyers in Frankfurt. ${ }^{67}$ But Sullivan \& Cromwell, the closest competitor to Davis Polk, supports a very different sort of mix in its Frankfurt office, where only three of fifteen lawyers have earned a U.S. J.D. The norm has shifted from the Davis Polk model, which might be characterized as "all U.S. all the time," to a model that offers a mix of local and U.S. lawyers, specializes in terms of practice focus, and might be characterized as "local matters."

Firms are increasing their international footprints while shaping themselves to local opportunities. The international U.S. firm of the future may be difficult to distinguish from firms based elsewhere, at least in terms of the kind of law advised upon and the educational and licensing qualities of their lawyers. This brings us back to Honda, which has shed the image of a foreign firm in the minds of Americans--they have rid themselves of their Japanese-ness in order to be more fully integrated and accepted in the United States. But in law, at least so far, it is precisely the American-ness of U.S. firms that has distinguished them from the competition. ${ }^{68}$ The question for the future is whether U.S. firms will want to maintain their American identities, and if they do, how they will go about that in light of their multinational staff and services.

\section{Appendix A: Firms Studied ${ }^{69}$}

(* indicates firm historically was based outside of New York)

\section{Akin Gump Strauss Hauer \& Feld*}

2. Arnold \& Porter*

3. Baker Botts*

4. Bingham McCutchen*

5. Bryan Cave*

6. Cadwalader, Wickersham \& Taft

67. Davis Polk \& Wardwell-Frankfurt Office Attorney Profiles, http://www.dpw.com/attysearch/ atty.search2.jsp? submitit= go\&office $=$ frank furt (last visited Oct. 10, 2006).

68. See generally Silver, supra note 6, at 1094-1100 (discussing what makes U.S. firms and their lawyers unique).

69. Two firms, Baker \& McKenzie and DLA Piper, would be included based upon their international presence and ranking, but are excluded here because information was available only for lawyers occupying certain, more senior, positions in the firms. Firms that did not provide information about their associate lawyers were excluded from the study, on the theory that younger lawyers are more likely to have a U.S. LL.M., and also are likely to comprise a larger portion of the staff of any particular office than are partners. Coudert Brothers also was excluded from the study because of its dissolution. 
7. Cleary Gottlieb Steen \& Hamilton

8. Covington \& Burling*

9. Cravath, Swaine \& Moore

10. Curtis, Mallet-Prevost, Colt \& Mosle

11. Davis Polk \& Wardwell

12. Debevoise \& Plimpton

13. Dechert*

14. Dewey Ballantine

15. Dorsey \& Whitney*

16. Duane Morris*

17. Faegre \& Benson*

18. Foley \& Lardner*

19. Fried, Frank, Harris, Shriver \& Jacobson

20. Fulbright \& Jaworski*

21. Gibson, Dunn \& Crutcher*

22. Greenberg Traurig*

23. Heller Ehrman*

24. Hogan \& Hartson*

25. Holland \& Knight*

26. Howrey*

27. Hughes Hubbard \& Reed

28. Hunton \& Williams*

29. Jones Day*

30. Kaye Scholer

31. Kelley Drye \& Warren

32. Kilpatrick Stockton*

33. Kirkland \& Ellis*

34. Latham \& Watkins*

35. LeBoeuf, Lamb, Greene \& MacRae

36. Mayer Brown Rowe \& Maw*

37. McDermott Will \& Emery*

38. McGuireWoods*

39. Milbank, Tweed, Hadley \& McCloy

40. Morgan, Lewis \& Bockius*

41. Morrison \& Foerester*

42. O'Melveny \& Myers*

43. Orrick, Herrington \& Sutcliffe* 
44. Paul, Hastings, Janofsky \& Walker*

45. Paul, Weiss, Rifkind, Wharton \& Garrison

46. Pillsbury Winthrop Shaw Pittman*70

47. Proskauer Rose

48. Reed Smith*

49. Schulte Roth \& Zabel

50. Seyfarth Shaw*

51. Shearman \& Sterling

52. Shook, Hardy \& Bacon*

53. Sidley Austin*

54. Simpson Thacher \& Bartlett

55. Skadden, Arps, Slate, Meagher \& Flom

56. Squire, Sanders \& Dempsey*

57. Sullivan \& Cromwell

58. Vinson \& Elkins*

59. Weil, Gotshal \& Manges

60. White \& Case

61. Willkie Farr \& Gallagher

62. Wilmer Cutler Pickering Hale \& Dorr*

63. Winston \& Strawn*

\section{Appendix B: Firms with Offices in London in 1990}

Baker \& McKenzie

Bingham Dana

Brown \& Wood

Bryan Cave

Cleary Gottlieb

Coudert

Covington \& Burling

Cravath

Curtis Mallet

70. Pillsbury Winthrop resulted from a merger of Pillsbury Madison \& Sutro and Winthrop Stimson Putnam \& Roberts in 2001; the latter was a New York-based firm. The firm since has acquired Shaw Pittman as well. The non-New York characterization is taken from the adoption of "Pillsbury" as the first name in the merged firm, which is taken as an indication of power in the resulting firm. 
Davis Polk

Debevoise

Dechert Price

Dorsey \& Whitney

Faegre \& Benson

Fried Frank

Fulbright \& Jaworski

Gibson Dunn

Graham \& James

Jones Day

Kilpatrick Stockton

Latham \& Watkins

LeBoeuf Lamb

Mayer Brown

Milbank, Tweed, Hadley \& McCloy

Morgan Lewis

Morrison \& Foerster

O’Melveny \& Myers

Paul Weiss

Proskauer Rose

Shearman \& Sterling

Sidley \& Austin

Vinson \& Elkins

White \& Case

Willkie Farr \& Gallagher

Wilmer Cutler

Wilson Elser

Winthrop Stimson 
